обліку [Текст] / С.Ф. Голов // Бухгалтерський облік і аудит. - 2007. - № 4. - С. 3-18.

5. Закон України «Про бухгалтерський облік та фінансову звітність в Україні» від 16.07.1999 р. №996-XIV. [Електронний ресурс]. - Режим доступу: http://zakon4.rada.gov.ua/laws/show/996-14.

6. Кірейцев Г.Г. Бухгалтерський облік та науковці, що генерують ідеї його розвитку / Г.Г. Кірейцев // Бухгалтерія в сільському господарстві. - 2008. - № 20. C. 3-7.

7. Національне положення (стандарту) бухгалтерського обліку 1 «Загальні вимоги до фінансової звітності», затверджене наказом Міністерства фінансів України від 07.02.2013 № 73. [Електронний ресурс]. - Режим доступу: http://zakon4.rada.gov.ua/laws/show/z0336-13.

8. Офіційний сайт «Державної служби статистики України» [Електронний ресурс]. - Режим доступу: http://www.ukrstat.gov.ua/.

*УДК 331.5(477)

Шубала I.В., к.е.н., доцент

Луцький національний технічний університет

\title{
ОЦІНКА ЕФЕКТИВНОСТІ РОБОТИ ЦЕНТРУ ЗАЙНЯТОСТІ ЩОДО УСУНЕННЯ ДИСПРОПОРЦІЇ НА РЕГІОНАЛЬНОМУ РИНКУ ПРАЦІ
}

У статті проведено оцінку ефективності роботи центру зайнятості щодо усунення диспропорції на ринку праці у Волинській області.

Ключові слова: ринок праці, центр зайнятості, диспропорції, працевлаштування, регіон.

\section{Shubala I.}

\section{EVALUATING THE EFFECTIVENESS OF THE EMPLOYMENT CENTER IN REMOVING IMBALANCES IN THE REGIONAL LABOR MARKET}

Basically, imbalances in the modern labor market arise due to a substantial excess of labor supply over demand, which generates a number of problems that negatively affect the level of socio-economic development of the country and individual regions. The purpose of the study is to analyze and assess the disparities in the labor market on the example of a separate region - the Volyn region.

By most indicators there is a deterioration of the work of the regional employment center in the direction of ensuring the effectiveness of facilitating job

* Шубала І.В. 
placement of the unemployed. It can be stated that the employment service as a whole is taking sufficient measures to employ persons who have additional guarantees of social protection. Among the positive results, employment growth can be highlighted from $34.1 \%$ in 2013 to $35.7 \%$ in 2017 . At the same time, there was a decrease in the effectiveness of active employment promotion measures.

During the last 8 years there has been a gradual decrease in the number of unemployed people who participated in public works (from 11.0 thousand people in 2010 to 7.3 thousand people in 2017 , or $33.9 \%$ ), and the number of unemployed The population of vocational education (from 5,4 thousand people to 3,7 thousand people, or almost 2 times), indicating a reduction in the scope of active measures to promote employment in the Volyn region, as well as the need to intensify work in this direction from attracting additional financial resources from the Social Insurance Fund for Unemployment. Significant fluctuations in the level of employment of the unemployed are associated with the peculiarities of the development of the labor markets of individual cities or regions that are sensitive to changes in the economic situation of certain enterprises or organizations, especially during the period of economic crisis and financial instability, which is characterized by a decrease in the demand for labor. In order to balance supply and demand in the labor market at the regional level, it is necessary to introduce the practice of forming a strategy for balancing supply and demand in the regional labor market, which should aim at eliminating imbalances between the interests of individual parties in social and labor relations. The paper proposes the procedure for elaboration and implementation of the strategy of balancing supply and demand in the regional labor market and the role in this process of the Territorial Tripartite Social and Economic Council. The organizational and managerial support of the activity of the Territorial Tripartite Social-Economic Council will be carried out by the Chairman of the Regional Council and the Chairman of the Regional State Administration. Regulatory and legal support of the activity of this structure will be carried out by the Volyn Regional Council. For its part, the tripartite council will provide the highest state authorities with information on the state of implementation of the strategy for balancing supply and demand in the labor market and proposals for improving the system of regulatory and organizational and managerial support in the field of social dialogue.

Key words: labor market, employment center, disproportion, employment, region.

\section{Шубала И.В. ОЦЕНКА ЭФФЕКТИВНОСТИ РАБОТЫ ЦЕНТРА ЗАНЯТОСТИ ПО УСТРАНЕНИЮ ДИСПРОПОРЦИИ НА РЕГИОНАЛЬНОМ РЫНКЕ ТРУДА}

В статье проведена оценка эффективности работы центра занятости по устранению диспропорции на рынке труда в Волынской области.

Ключевые слова: рынок труда, центр занятости, диспропорции, трудоустройство, регион. 
Постановка проблеми у загальному вигляді і їі зв'язок 3 важливими науковими та практичними завданнями. Практика господарювання показує, що сучасний ринок праці України характеризується незбалансованістю попиту і пропозиції робочої сили. Тому на сучасному етапі необхідно створити комплексну систему аналізу та оцінки попиту і пропозиції на ринку праці на регіональному рівні. Важливо, створити таку систему соціально-трудових відносин на регіональному рівні, яка б дозволила уникнути утворення будь-яких дисбалансів на ринку праці. Основі дисбаланси на сучасному ринку праці виникають через суттєве перевищення пропозиції робочої сили над попитом на неї, що породжує низку проблем, які негативно позначаються на рівні соціально-економічного розвитку країни та окремих регіонів.

Аналіз останніх досліджень, у яких започатковано вирішення проблеми. Вирішенням багатьох прямо чи опосередковано визначених проблем, які пов'язані із уникненням диспропрцій на ринку праці та формування ефективної системи соціальнотрудових відносин на регіональному рівні займалися багато вітчизняних учених: А. Базилюк, С. Бандур, Д. Богиня, I. Бондар, В. Васильченко, В. Гриньова, М. Долішній, С. Злупко Г. Купалова, В. Куценко, Е. Лібанова, В. Новіков, В. Онікієнко, В. Онищенко, Н. Павловська, В. Петюх, М. Шаленко, В. Шамота, Л. Черчик, I. Шубала та багато ін. Отримані напрацювання повинні стати теоретико-методологічною базою для подальшого вирішення проблем збалансування попиту і пропозиції на робочу силу, а також усунення інших диспропорцій на ринку праці регіонального рівня, що й стало підставою для вибору напрямку подальшого дослідження.

Цілі статті. Мета дослідження полягає в проведенні аналізу та оцінки диспропорцій на ринку праці на прикладі окремого регіону - Волинської області.

Виклад основного матеріалу дослідження з повним обгрунтуванням отриманих наукових результатів. Аналіз руху робочої сили на регіональному рівні повинен охоплювати багато різноманітних аспектів, що стосуються зміни чисельності штатних та позаштатних працівників підприємств, показників прийняття та звільнення персоналу, плинності кадрів тощо. 
Початковий етап аналізу передбачає узагальнення даних внутрішньої звітності та проведення комплексного аналізу зміни основних показників роботи Волинського обласного центру зайнятості за 2013-2017 pр. (табл. 1).

В цілому це дозволить зробити узагальнені висновки про ефективність реалізації державної політики сприяння працевлаштуванню безробітних у регіоні. Загалом протягом аналізованого періоду відбулося зменшення кількості осіб, які мали статус безробітного на 21,9\%, у тому числі осіб, які мали додаткові гарантії у сприянні працевлаштуванню. 3 іншого боку, спостерігається і зменшення кількості працевлаштованих безробітних - на 18,0\%, але щодо осіб, які мають додаткові гарантії у сприянні працевлаштуванню цей показник зріс. Також серед позитивів можна виділити зростання рівня працевлаштування з 34,1\% у 2013 році до 35,7\% у 2017 році. Разом з тим відбулося зменшення ефективності активних заходів сприяння працевлаштуванню.

Також бачимо, що на фоні зменшення кількості осіб, які проходили профнавчання на $33,5 \%$, відбулося зростання кількості залучених безробітних до виконання громадських робіт та інших робіт тимчасового характеру на $21,4 \%$. Середній розмір допомоги по безробіттю за аналізований період зріс більше, ніж удвічі та у 2017 році становив 2088 грн.

Таблиця 1

Основні показники роботи Волинського обласного центру зайнятості за 2013-2017 pp.

\begin{tabular}{|l|c|c|c|c|c|c|c|}
\hline \multicolumn{1}{|c|}{ Показники } & $\begin{array}{c}2013 \\
\text { рік }\end{array}$ & $\begin{array}{c}2015 \\
\text { рік }\end{array}$ & $\begin{array}{c}2016 \\
\text { рік }\end{array}$ & $\begin{array}{c}2017 \\
\text { рік }\end{array}$ & $\begin{array}{c}2016 \mathrm{p} . / \\
2015 \mathrm{p} .\end{array}$ & $\begin{array}{c}2017 \mathrm{p} . / \\
2016 \mathrm{p} .\end{array}$ & $\begin{array}{c}2017 \mathrm{p} . / \\
2013 \mathrm{p} .\end{array}$ \\
\hline 1 & 2 & 3 & 4 & 5 & 6 & 7 & 8 \\
\hline $\begin{array}{l}\text { Мали статус безробітного } \\
\text { протягом звітного періоду }\end{array}$ & 37955 & 36463 & 33430 & 29653 & $-8,3$ & $-11,3$ & $-21,9$ \\
\hline \begin{tabular}{l} 
Працевлаштовано, всього \\
\hline $\begin{array}{l}\text { Рівень працевлаштування, } \\
\%\end{array}$
\end{tabular} & 12925 & 12528 & 11894 & 10603 & $-5,1$ & $-10,9$ & $-18,0$ \\
\hline Проходили профнавчання & 5609 & 54,4 & 35,6 & 35,7 & 3,5 & 0,3 & 4,7 \\
\hline $\begin{array}{l}\text { Брали участь у громад- } \\
\text { ських роботах та інших } \\
\text { роботах тимч. характеру }\end{array}$ & 6028 & 7991 & 7057 & 7318 & $-11,7$ & 3,7 & 21,4 \\
\hline
\end{tabular}


Продовження табл. 1

\begin{tabular}{|c|c|c|c|c|c|c|c|}
\hline 1 & 2 & 3 & 4 & 5 & 6 & 7 & 8 \\
\hline $\begin{array}{l}\text { Середній розмір допомо- } \\
\text { ги по безробіттю у грудні, } \\
\text { грн. }\end{array}$ & 989,7 & 1329,9 & 1927,8 & 2088,4 & 45,0 & 8,3 & 111,0 \\
\hline $\begin{array}{l}\text { Кількість зареєстрованих } \\
\text { безробітних на кінець } \\
\text { року }\end{array}$ & 11088 & 11739 & 9200 & 8179 & $-21,6$ & $-11,1$ & $-26,2$ \\
\hline \multicolumn{8}{|l|}{3 них: } \\
\hline жінки & 6258 & 6811 & 4595 & 4767 & $-32,5$ & 3,7 & $-23,8$ \\
\hline молодь у віці до 35 p. & 5663 & 5312 & 3702 & 3174 & $-30,3$ & $-14,3$ & $-44,0$ \\
\hline \begin{tabular}{|} 
особи, що проживають \\
у сільській місцевості
\end{tabular} & 4355 & 5055 & 4333 & 3457 & $-14,3$ & $-20,2$ & $-20,6$ \\
\hline $\begin{array}{l}\text { Отримують допомогу по } \\
\text { безробіттю }\end{array}$ & 9069 & 9672 & 7492 & 6503 & $-22,5$ & $-13,2$ & $-28,3$ \\
\hline $\begin{array}{l}\text { Кількість вакансій на } \\
\text { кінець року }\end{array}$ & 531 & 782 & 1648 & 2227 & 110,7 & 35,1 & 319,4 \\
\hline
\end{tabular}

Примітка. Розроблено автором на основі джерел [1-6].

Поряд 3 цим, спостерігається зменшення станом на кінець відповідних років серед зареєстрованих безробітних осіб, зокрема, жінок (на 23,8\%), молоді у віці до 35 років (на 44,0\%), осіб, які проживають у сільській місцевості (на 20,6\%). Натомість збільшилася кількість осіб, які мають додаткові гарантії у сприянні працевлаштуванню, зменшилася кількість осіб, які отримують допомогу по безробіттю (на 28,3\%), а кількість вакансій на кінець року навпаки зросла (у 4 рази з 2013 році). Тобто за більшістю показників спостерігається погіршення роботи обласного центру зайнятості у напрямі забезпечення ефективності сприяння працевлаштуванню безробітних.

Надалі виникає необхідність проведення детальнішого аналізу зміни кількості осіб, які мають додаткові гарантії соціального захисту, працевлаштованих Волинським обласним центром зайнятості у 2015-2016 роках (рис. 1). 
Економічні науки". - Серія "Облік і фінанси". - Випуск 15 (57). - 2018.

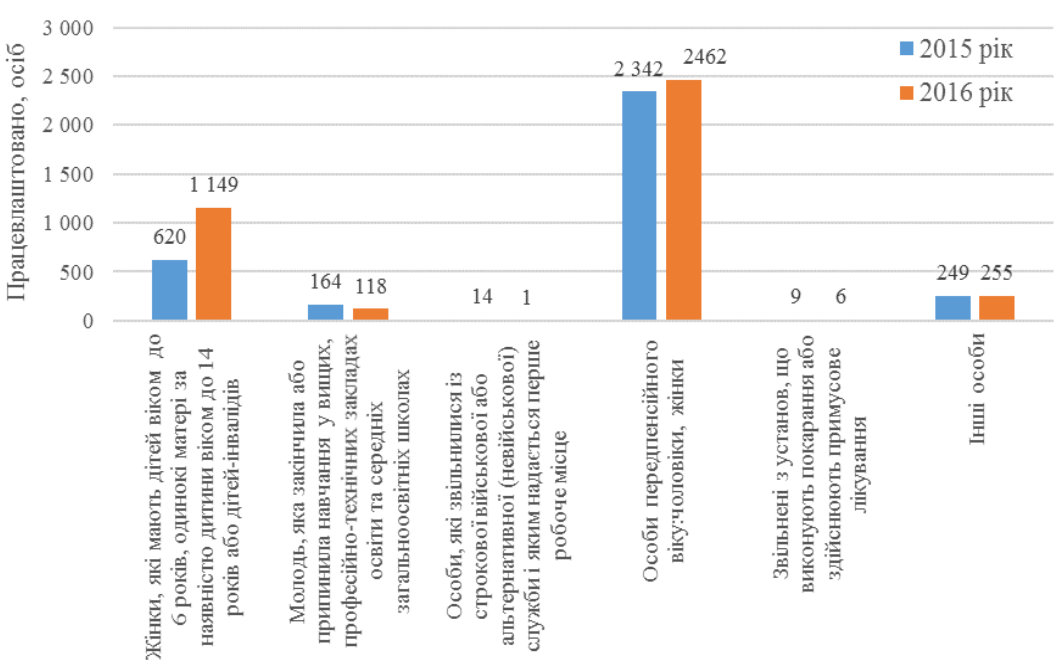

Рис. 1. Динаміка кількості осіб, які мають додаткові гарантії соціального захисту, працевлаштованих Волинським обласним центром зайнятості у 2015-2016 роках (побудовано автором на основі даних [1-6])

Як бачимо з рисунку, загалом спостерігалося збільшення кількості осіб, які мають додаткові гарантії соціального захисту, працевлаштованих Волинським обласним центром. Особливо значним цей показник $є$ у працевлаштуванні осіб передпенсійного віку, кількість яких збільшилася й у 2017 році становила 2462 осіб. Також значна увага приділяється працевлаштуванню жінок, які маю дітей до 6 років та інші соціальні пільги, яких у 2017 році було працевлаштовано 1149 осіб, тобто майже у 2 рази більше, ніж у попередньому році. Тому можна констатувати, що служба зайнятості в цілому проводить достатньо заходів для працевлаштування осіб, які мають додаткові гарантії соціального захисту.

На наступному етапі аналізу проведено порівняння зміни кількості безробітних, які проходили професійне навчання та брали участь у громадських роботах у Волинському обласному центрі зайнятості за 2010-2017 pp. (рис. 2). 
Економічні науки". - Серія "Облік і фінанси". - Випуск 15 (57). - 2018.

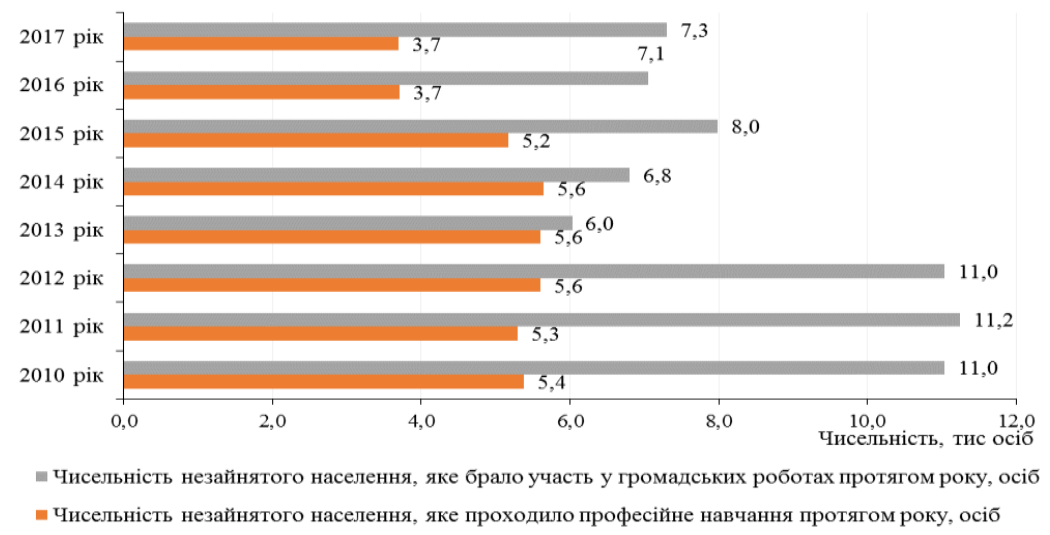

Рис. 2. Порівняння зміни кількості безробітних, які проходили професійне навчання та брали участь у громадських роботах у Волинському обласному центрі зайнятості за 2010-2017 pp. (побудовано автором на основі даних [1-6])

Отже, протягом останніх 8 років відбулося поступове зменшення як чисельності незайнятого населення, яке брало участь у громадських роботах (з 11,0 тис осіб у 2010 році до 7,3 тис осіб у 2017 році, або на 33,9\%), так і чисельності безробітного населення, яке проходило професійне навчання (3 5,4 тис осіб до 3,7 тис осіб, або майже у 2 рази), що свідчить про зменшення масштабів реалізації активних заходів сприяння працевлаштуванню у Волинській області, а також необхідність активізації роботи у цьому напрямі із залученням додаткових фінансових ресурсів з Фонду соціального страхування на випадок безробіття.

Слід відмітити, що найважливішою функцією Волинського обласного центру зайнятості та його структурних підрозділів є забезпечення якнайшвидшого працевлаштування незайнятого населення, яке перебуває на обліку як безробітні. Тому виникає необхідність детальнішого вивчення динаміки кількості зареєстрованих безробітних, потреби роботодавців у працівниках для заміщення вільних робочих місць (вакантних посад) та кількості працевлаштованої робочої сили за видами економічної діяльності у Волинській області. 
Відповідно, на наступному етапі аналізу вивчено динаміку рівня працевлаштування незанятих громадян через Волинський обласний центр зайнятості за 2011-2017 рр. (рис. 3).

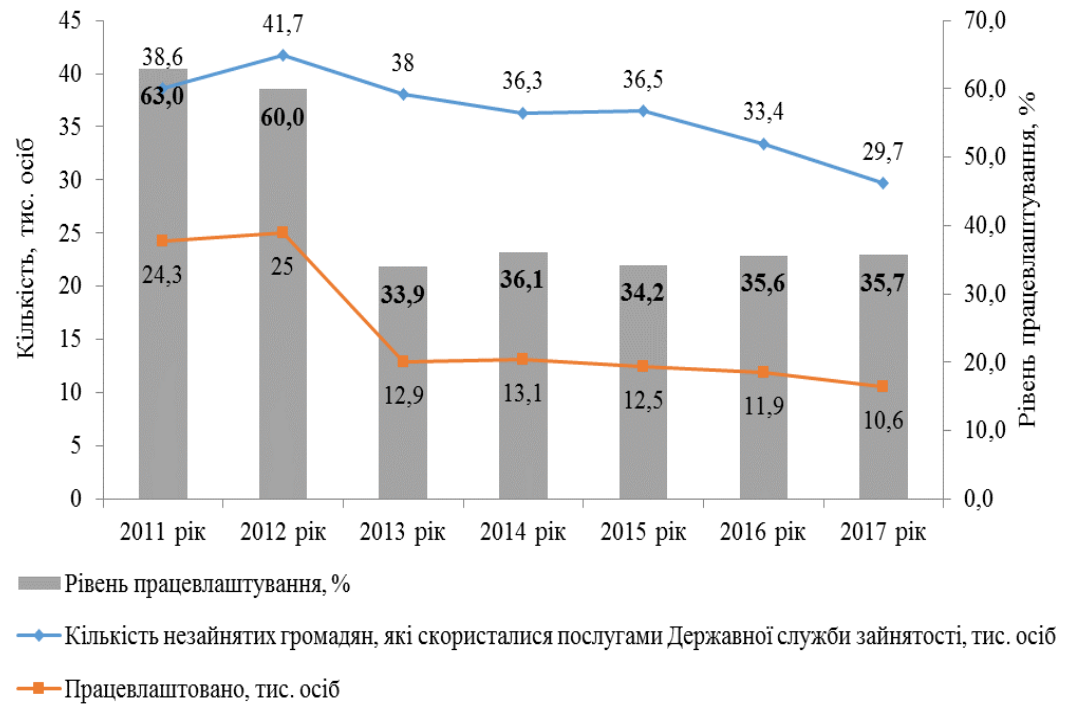

Рис. 3. Динаміка рівня працевлаштування незанятих громадян через Волинський обласний центр зайнятості за 2011-2017 pp. (побудовано на основі даних [1-6])

Такі значні коливання рівня працевлаштування безробітних пов'язуються з особливостями розвитку ринків праці окремих міст чи районів, які чутливі до зміни економічної ситуації на окремих підприємствах або організаціях, особливо в період економічної кризи та фінансової нестабільності, що характеризується зменшенням попиту на робочу силу.

Висновки. 3 метою збалансування попиту і пропозиції на ринку праці регіонального рівня потрібно запровадити практику формування стратегії збалансування попиту і пропозиції на регіональному ринку праці, яка повинна бути спрямована на усунення дисбалансів між інтересами окремих сторін соціально-трудових відносин. У роботі запропоновано порядок розробки та реалізації стратегії збалансування попиту і пропозиції на регіональному рин- 
ку праці та роль у цьому процесі Територіальної тристоронньої соціально-економічної ради.

Організаційно-управлінське забезпечення діяльності Територіальної тристоронньої соціально-економічної ради здійснюватимуть Голова обласної ради і Голова облдержадміністрації. Нормативно-правове забезпечення діяльності цієї структури здійснюватиме Волинська обласна рада. Зі свого боку тристороння рада надаватиме найвищим органам державної влади інформацію про стан виконання стратегії збалансування попиту і пропозиції на ринку праці та пропозиції щодо удосконалення системи нормативноправового та організаційно-управлінського забезпечення у сфері соціального діалогу.

1. Волинь-2016: статистичний щорічник / За ред. В.Ю. Науменка. - Луцьк: Головне управління статистики у Волинській області, 2017. - 457 с.

2. Головне управління статистики у Волинській області : офіційний веб-сайт [Електронний ресурc]. - Режим доступу: http://www.lutsk.ukrstat.gov.ua.

3. Праця Волині-2014: статистичний збірник / За ред. Л.С. Баранюк. - Луцьк: Головне управління статистики у Волинській області, 2015. - 107 с.

4. Праця Волині-2015: статистичний збірник / За ред. В.О. Грабаровської. Луцьк: Головне управління статистики у Волинській області, 2016. - 116 с.

5. Праця Волині-2016: статистичний збірник / За ред. В.О. Грабаровської. Луцьк: Головне управління статистики у Волинській області, 2017. -103 с.

6. Праця Волині-2017: статистичний збірник / За ред. В.О. Грабаровської. Луцьк: Головне управління статистики у Волинській області, 2018. - 128 с.

*УДК 351.84

Шубалий О.М., д.е.н., професор

Андрусик I.O.

Луцький національний технічний університет

\section{СТАН І ПЕРСПЕКТИВИ ВДОСКОНАЛЕННЯ СОЦІАЛЬНОГО ЗАХИСТУ НАСЕЛЕННЯ У РЕГІОНІ}

У статті проведено оцінку стану і обгрунтовано перспективні напрями вдосконалення соціального захисту населення на прикладі Волинської області.

Ключові слова: соціальний захист, доходи населення, соціальні допомоги, середня заробітна плата, пенсія, регіон.

* Шубалий O.М., Андрусик I.O. 
Економічні науки". - Серія "Облік і фінанси". - Випуск 15 (57). - 2018. 